\title{
Thoughts on Some Conceivable Ecodisasters
}

\author{
by \\ Nicholas Polunin, D.Phil., D.Sc.(Oxon.)
}

Secretary-General, International Conferences on Environmental Future; Founder and Editor of Environmental Conservation, etc., 15 Chemin F.-Lehmann, 1218 Grand-Saconnex, Geneva, Switzerland.

\begin{abstract}
INTRODUCTION
The term 'ecodisaster', which I think we initiated at our first International Conference on Environmental Future, held in Finland in June-July 1971, may need explaining. A disaster being a 'sudden or great misfortune', and an 'eco-' anything referring to a habitat or the wider environment-as in ecology, ecosystem, ecospecies, and many more jocular terms that are being introduced nowadays - combining the two gives us a term that is now proving widely useful." 'Ecodisaster' seems preferable to the longer and more definitive 'ecocatastrophe', implying a disastrous or ruinous end, for something which widely affects Man's and/or Nature's environment very adversely but not necessarily finitely. It may be either long- or short-term, and either anthropocentric or concerned with the wider interests of Nature; usually it concerns both Man and Nature. It may be caused by Man or otherwise, and range from being grandiosely striking to quite insidious, or from fully global to micro-local; but in any case it is disastrous to the environment, be it widely or only locally. For we must remember always that these things are relative in their impress and scope; to a worm living under a stone, the removal of that stone by whatever means may constitute an ecodisaster of the most crucial importance. In this paper we shall, however, concern ourselves only with matters of wide import-most of them constituting conceivable threats to the biosphere-for such are already far too numerous and diverse. And most of what we shall call 'conceivable' ecodisasters are no more; for whereas many of them are indeed all too possible, they are not by any means all going to happen together, and many of them surely will never happen. Nor do we attempt to offer solutions, but merely to catalogue much of what seems conceivable. We shall not even restrict ourselves to effects produced

* See, for example, the posthumous paper of our lamented Colleague, Desmond F. Vesey-FitzGerald, entitled 'On a State of Naturalness', published on pp. 231-2 of this issue.
\end{abstract}

by Man, though most of them are the results, either directly or indirectly, of his activities since he became the overwhelming superdominant of the living world.

A few years ago I had detailed discussions concerning these and allied matters with the virtual ruler of the second most populous nation on Earth-a talented and attractive lady who, however, seemed unaware of many of the worst pitfalls. She even thought that human population growth could continue with impunity and that the 'green revolution' had come to stay! Yet although further drastic increase in the present mass of humanity - which for short we might term a 'demomass'-is surely undesirable to say the least, the actual expectation is that "even if we stabilize the population growth by the year 2000 in the advanced countries and by 2040 in the developing countries, we will still have some 15.5 thousand million people on Earth at the end of the twenty-first century' (Henderson, 1972). This is around four times the present computed 4,000,000 people on Earth (Ehrlich, 1974), who are already having such a devastating effect on the world that many thinking people believe they are jeopardizing their very chance of survival. Yet we must avoid fatalism ('it is the will of God') and alarmism ('no use trying') and any unwarranted crying of 'wolf'. On the other hand we must be forewarned of possibilities of dangers ahead, and look out for others of which we have not yet any conception-indeed probably there are many which have not yet been conceived, in the sense that only changed and unforeseen circumstances will engender them. Here we need only recall the cases of PCBs and SSTs, and the dangers of widespread development of nuclear energy even if it is limited to peaceful ends.

Let us as scientists be careful to base our definite statements on known and demonstrable facts, and as concerned scholars consider chosen items as mere conceivabilities, while recognizing that there are plenty more. They range from some ecodisasters which appear inevitable if present trends continue 
to others which, because of intervening circumstances, are simply not going to happen. The seemingly inexorable rise of human population is continuing as we deliberate, and the projection to around at least four times its present level in due course is widely quoted and believed. Leading demographers and ecologists, however, think that such a total will never be reached, that something must intervene on a sufficient scale to prevent it (Ehrlich \& Ehrlich, 1972; Ehrlich et al., 1973; Ehrlich, 1974). This indeed seems likely - though whether it will be by nuclear holocaust, disease and pestilence, social breakdown with anarchical killing, widespread starvation, or yet otherwise, we can at present only conjecture. Unfortunately it seems unlikely that it will be through 'peaceful' means of population control, even if we manage to overthrow some current religious and tribal teachings and to outgrow our beliefs in the unrestricted primacy of mankind.

With the force of these conceptions (which often amount to convictions), and with modern medical and other practices operating in varying degrees throughout the world, the situation of the human species has become a near-classic one of population swarming, of which biologists are all-too-familiar with the outcome: think only of the alliteration of lemmings in Scandinavia, of locusts in the Sahara, and of lampreys in the Great Lakes of North America -but project the phenomenon to world-wide dimensions to involve that most ubiquitous of large biota, Homo sapiens agg.! Clearly Man could exceed, even without realizing it until too late, the carrying capacity of the biosphere for his demomass and for much else besides. In the end his ubiquitous and profligate numbers will be controlled, that is certain: but how? And what and where are the conceivable ecodisasters and other changes that at present seem most likely to participate in this control and other major events? Let us consider a selection under ten general headings, confining ourselves to touching on three problems (given separate paragraphs) under each of these headings, though commonly there are more which are already conceivable. Often there is substantial overlap, but this seems inevitable in biological categorization.

\section{ATMOSPHERE}

Let us start by dealing with the atmosphere, in the lower, ambient layers of which we and most other animals and plants largely live. Although the oxygen content on which we depend for respiration and combustion has varied scarcely at all in recent times in spite of ever-increasing use, and so gives us no urgent cause for concern, the same is unfortunately by no means the case with carbon dioxide. The ambient atmospheric content of this gas has increased by at least 6 and probably nearer 10 or even more per cent since the turn of the century (F. S. Johnson, 1970; Attiwill, 1971), and although it is still only slightly over three parts in ten thousand, or actually about 0.032 per cent by weight, this and foreseeable further increases give us cause for considerable concern. To be sure, the augmented concentration may well increase still further the extraordinary efficiency displayed by greeen plants in their photosynthetic activity which is the basic source of food for almost all life on Earth, but it also has other, sinister effects. Notable among these is the 'greenhouse' or 'hothouse' effect of reducing re-radiation into the upper atmosphere of heat-energy acquired from the sun by the Earth's surface, so tending to increase the temperature at and immediately around that surface slightly but quite appreciably. For whereas the carbon dioxide and other gases of the atmosphere are virtually transparent to the visible radiation that delivers the sun's energy to the Earth, the latter in turn re-radiates much of this energy in the invisible infra-red region of the spectrum that is absorbed by carbon dioxide. There is concern that, with the ever-increasing burning of petroleum and other 'fossil fuels' throughout the world, coupled with the respiratory and agricultural activities of an ever-increasing demomass, the build-up of carbon dioxide in the atmosphere could ultimately lead to major climatic and concomitant changes-resulting, for instance, in the ultimate melting of the Antarctic and Greenland and other ice-caps. This could lead to a raising of ocean levels by up to some 50 metres, causing the disappearance, under the surface of the extended oceans, of many of the major cities of the world and of vast areas of the best agricultural land. At least for the human family we would now need considerably more of an Ark than Noah did! To the greenhouse effect of carbon dioxide should be added that of water vapour and ozone emitted particularly by aircraft and automobiles near the Earth's surface, and also the heat of burning and other human activities (Fremlin, 1964). Could not a resultant increase in temperature drive enough carbon dioxide from the oceans (which are its greatest reservoir) into the atmosphere, to amplify the increase to the point of instability (cf. F. S. Johnson, 1970), for example by triggering a cumulative build-up with ever-more atmospheric carbon dioxide leading to an everincreasing greenhouse effect and hence temperature rise and continuing feed-back driving yet more carbon dioxide from the oceans (cf. N. Polunin, 1974)? At present we appear to be saved from any incidence of this conceivable ecodisaster by ocean buffering and by increased particulate pollution in the atmosphere reducing the amount of solar energy reaching the 
Earth's surface, so that our climate has tended to get slightly cooler in the last three decades (Wendland \& Bryson, 1970; Bryson, 1972a). But this last is a fortunate circumstance on whose continuance we should not rely-yet which, if it mounted up too strongly, might have other conceivably disastrous effects.

The above and any other tendency to climatic change must be monitored continuously and studied with alacrity if other conceivable ecodisasters are not to creep up on us and even reach a point of no return; for the insidious or even totally unrecognized dangers could well turn out to be among the worst. What, for example, is behind the present apparent redistribution of sufficient of the world's rainfall to wash away the potentiality of wheat surplus in the Mississippi region and destroy a reported $95 \%$ of the crops of Bangladesh just when some other major cereal-producing areas are experiencing such devastating droughts that they themselves may yet need that very surplus and their surrounding populations surely will? Is it not possible, for example, that the devastating drought in northwestern Africa of recent years could be connected with the widespread pollution of the parts of the Atlantic Ocean lying to the west? At present it seems more likely that the latest drought was cyclic in the manner indicated by earlier records, and exacerbated more by recent population increases and pressures than by actually reduced rainfall from whatever cause. But meanwhile we should realize that the distributions of crops do not require the evident advance of ice-caps or deserts to change them; although Man is a relatively feeble creature, by vesting himself in clothes and buildings he can largely combat climatic vagaries, whereas many of the biota on which he is dependent cannot, even though he may modify them and their ranges quite markedly by breeding and pampered cultivation.

Although the widespread catalyzed or chainreaction combination of nitrogen and oxygen to deplete the latter in the atmosphere is scarcely a conceivability (according to atmospheric and other chemists whom I have consulted), depletion of the stratospheric ozone shield evidently is a distinct possibility (Johnston, 1972, 1974; NAS/NAE, 1973), and could lead to almost as great, though presumably far slower, an ecodisaster. For it could allow increased penetration of lethal ultraviolet radiation into the biosphere, thus conceivably leading to a gradual ending of most life on land and much of that in water, and meanwhile to all manner of undesirable changesincluding, in humans, accelerated ageing and increased incidence of skin-cancer. Whether or not the objections to supersonic transport aircraft (SSTs) on this score are invalidated by observations on the effects of nuclear testing and rockets, as has latterly been contended, it would seem nothing short of criminal folly to proceed with the development of fleets of such SSTs until their possible effects on the stratosphere in which they mainly fly are fully known (NAS/NAE, 1973; N. Polunin, 1972, 1973; Johnston, 1974). For among other things they spew out vast quantities of water vapour and oxides of nitrogen $\left(\mathrm{NO}_{\mathrm{x}}\right)$, which between them are known in the laboratory to have quite numerous ways of catalyzing the destruction of ozone, while SSTs are apt to fly largely at an altitude not so very far below that of maximum concentration of ozone in the stratosphere!

\section{SOILS}

Even as green plants are the mainstay of the organic world, so are soils the main determinant of their productivity on land. Details are too immensely complicated and variable to give here, but as a broad generalization it may be said that, of the world's ca 14 thousand million hectares of ice-free land, only about 24 per cent are potentially arable farmland, of which only about one-third is actually cultivated (President's Science Advisory Committee, 1967; Murdoch, 1971). Yet from the former world total of potentially productive terrain, it is said that already about one-fifth has been lost to productivity-over wide areas not merely from agricultural crops but even from desirable 'natural' vegetation-while most of the other currently uncultivated areas could only be made agriculturally productive through drastic and costly irrigation, etc. So except for sub-Saharan Africa and the Amazon Basin - in both of which the potentiality is now being alarmingly destroyed-most of the normally cultivable areas of the world are already in use (ibid.), yet are themselves being destroyed at a rate which, if continued, it has been claimed would practically turn the world into a desert in 150 years (Goldsmith, 1973). Thus long-continued deforestation and other such devegetation could indeed be a major ecodisaster per se.

Widespread vegetation clearance and over-use of soils can also be a great danger, leading to erosion, salinization, or nutrient depletion-often accompanied by laterization or other structural breakdown which may be practically irreversible (Scientific American, 1971; Kovda, 1972). Particularly do deforestation and cultivation lead to erosion of soil from slopes, irrigation on flat areas without drainage lead to salinization of soils beyond the point of tolerance of any crop, and nutrient depletion with structural breakdown lead to the need of long periods of fallow or other treatment which cannot be afforded in developing regions. Even the use of fertilizers can have its dangers-especially if overdone, when it 
can lead to serious consequences more immediately in adjacent fresh waters. Overgrazing, and depletion of ground-water reserves when too extensively and protractedly pumped up for irrigation, etc., can lead to ever-extending desertification as in the southern Sahara region and elsewhere in Africa (CloudsleyThompson, 1974; Curry-Lindahl, 1974a, 1974b). All these and various other soil-connected tendencies are apt to cause local ecodisasters which can extend to assume proportions that are of serious consequence to the wider world, and together mount up enormously.

The so-called 'green revolution' is something of a dangerous fallacy, inter alia in connection with soils. For it involves 'flogging' them through heavy use of fertilizers to grow new, early-maturing 'high-yield' strains of grain-crops, particularly of wheat and rice. As emphasized by Ehrlich \& Ehrlich (1972), 'this cannot possibly keep food production abreast of population growth for more than two decades or so', while creating or exacerbating all manner of local problems-of over-enrichment of run-off waters and hence of lakes and rivers, of susceptibility to insect attacks and plant diseases, of pesticides to control such scourges but often having deleterious ecological side-effects, of loss of reserves of gentic variability needed for the continuing development of new strains, of irrigation and other water supplies, of needs for special research and technology, of human foodpreferences and working habits, of financing and suitable education, of supply and distribution, and yet other problems besides-including, doubtless, some resulting from concomitant population increases with an improved food situation when it proves to be only temporary. So at best the bases of the green revolution seem insecure, and at worst it could add to our sad tally of conceivable ecodisasters operating on a wide and devastating scale. One of these could be through deficiencies of phosphorus, an element essential for life, of which more and more is being washed down into the sea and, foreseeably, less and less will be recovered.

\section{DEVEGETATION}

With the doubling-time of human population now only about 35 years, if its growth continued at that rate the world population would exceed a trillion (an American billion billion) of people about 1,000 years hence-or slightly over 2,000 persons per square metre of the Earth's surface, land and sea (Ehrlich \& Ehrlich, 1972). Long before anything like this could happen there would be no foreseeable possibility for vegetation to grow, feed us, return oxygen to the air, and do various other things for Man and Nature that the world relies on whether we realize it or not. Indeed it is unthinkable on this score alone. For not only would there be precious little space for natural vegetation, however strong the preservationist movement of mankind, but even the most unnatural of perpetually fertilized monocultures on the tops of many-hundredstoreyed buildings would be utterly insufficient to feed anything approaching such a human population. And even those who think that 'science will find a way' have to admit that animals need feeding, and that Man is an animal and is likely so to remain to the end as it was in the beginning. Meanwhile the deforestation of which we have already spoken goes on apace, as does wider devegetation of scrub and grass and other land-all too often with devastating results of soil erosion, floods, nutrient depletion, and general loss of importantly productive and aesthetically attractive terrain. I need not dwell on details: you can all think of examples, often near your homes or those of friends. The tendency is fast assuming the scale of a major ecodisaster in more and more parts of the world-not merely in Amazonia and elsewhere in Latin America (S. Johnson, 1970), the Sahel region of Africa, and perhaps most widely in southeastern Asia.

Now what of gaseous exchanges? We have dwelt on some aspects of the importance of carbon dioxide, indicating the possible dangers of its increasing build-up in the atmosphere. It is absorbed by green plants for the all-important process of photosynthesis, and so the more of these that disappear, the more carbon dioxide will tend to be left in the air and in water both fresh and salt. This may increase the photosynthetic productivity of the remaining plants; but whether such increase, demonstrated under laboratory conditions, could possibly be on a sufficient scale to compensate for widespread devegetation, must remain to be seen, and would in any case depend partly on other factors such as availability of water and light which are the remaining main chemical and physical prerequisites for photosynthesis. Still other factors are vital, and here we should mention that the effects of certain pollutants on chlorophyll and its functioning can be profoundly disturbing; yet that functioning in photosynthesis is one of the two most fundamental metabolic activities in the world, being the basis of almost all food-building. The other is respiration, involving the breakdown of elaborated food to liberate energy, and it too is apt to be attacked by pollutants. This brings us to think of oxygen, the fundamental importance of which I need not emphasize. Practically all of the nearly 21 per cent by volume of oxygen in the atmosphere has been returned thereto by green plants as a by-product of photosynthesis-as to some 70 per cent of it, from the oceans. But although any loss of photosynthetic activity with a widespread disappearance of green plants (such as phytoplankton 
of the oceans) would entail less use of carbon dioxide and ultimately of oxygen to break down the products of photosynthesis, one's imagination boggles at the ecodisaster that such a change might effect in the working of the biosphere. And meanwhile the atmospheric carbon dioxide would build up from lack of use, from burning as we have already seen, from respiration of the zoobiomass in general and of the demomass in particular, and also from the necessary stressing of short-term crops in place of standing natural vegetation with its attendant litter of humus storing carbon dioxide and energy more or less protractedly. But whereas oxygen is the most abundant element of all, nitrogen holds that position only in the atmosphere, of which it constitutes slightly over 78 per cent by volume; yet it comprises some 18 per cent of protein, 'the main stuff of life', so we must beware any possible interference with the 'nitrogen cycle' in which it is returned to the atmosphere (Scientific American, 1971).

Our third chosen item under this general heading concerns the water or hydrological cycle. The world's atmosphere at any one time contains a computed average of some 13 to 14 thousand cubic kilometres of water, mostly in the form of clouds and vapour; this comprises only about 0.0009 per cent of the world's total water, and its average renewal time is variously given as from nine to twelve days (Murdoch, 1971; Vallentyne, 1972). The total transpiration of the world's vegetation is calculated at about 40,000 cubic kilometres of water per year (Worthington, 1972), which means that about a month's supply of water vapour is added yearly to the atmosphere by vegetation-mostly by forests. Devegetation in general, and deforestation in particular, will reduce this supply and, especially if coupled with reduction in evaporation from the oceans, which at present are responsible for the return of probably about 84 per cent of the water vapour in the atmosphere, could have quite devastating effects on climate and, for example, contribute to disastrous droughts.

\section{FRESH WATERS}

Without attempting to deal with the often horrendous scares regarding the possible effects of foreseeable water shortages to which we are apt to be subjected through 'the media', but which seem the more exaggerated when we consider the potentialities of desalination, there is no question that widepread and prolonged water-shortage could constitute a major ecodisaster. Thus droughts can cause famines which can have grave side-effects-including, foreseeably, desecration of nature reserves and consumption of their inhabitants both animal and plant. This could involve destruction of unique ecosystems and loss of irreplaceable gene-pools. The conceivability seems the more possible when we remember that what we are mainly dependent on is gaseous and liquid fresh water, which is mostly ground-water but still comprises probably less than one-third of the about three per cent of water on Earth which is fresh, the other two-thirds of fresh water being frozen and the remaining 97 or so per cent of all Earth's water being in the oceans (Nace, 1967; Vallentyne, 1972).

As for poisoning and other pollutions of our alltoo-limited fresh waters, the agents are legion and cases cropping up all the time. When involving such major fish-kills as that which occurred in the Rhine a few years ago, with inevitable side-effects, they may be considered as ecodisasters on the local or regional scale, and the same may be the case where the water supply is contaminated to the extent of poisoning people and livestock. Of this there exist almost endless possibilities, quite apart from the heavy metals and certain insecticides and polychlorinated biphenyls (PCBs); moreover, with the computed half-million known pollutants being added to at an alleged rate of 1,000 annually (Goldsmith, 1973), Man had better watch out as his life increases in complexity and intricacy with his ever-mounting numbers and demands on the limited resources of the biosphere (N. Polunin, 1972, 1974).

A special case is the over-enrichment which is widely termed 'eutrophication'. This commonly involves fresh waters but can also apply to soils and seas and, ultimately, the world ocean. The chief offenders in many places appear bo be chemical fertilizers, of which the amounts applied to soils annually in the world (apart from mainland China, North Korea, and North Vietnam) have risen from $6,444,000$ metric tons in 1930-31 to $58,960,000$ metric tons in 1969-70 (A. H. Boerma in litt., 1971); consumption rose by $8 \%$ in the following year (FAO, 1972) and continues to rise. But unsatisfactory sewage disposal and run-off from cattle feed-lots can also have unfortunate effects, and so can other pollutions through abnormal favouring of particular forms of life and even unwise deforestation. As a result, lakes may become 'dead', though this disclaimer often refers more to their unsavoury odour and lack of desirable fish and other life than to any lack of life altogether; indeed such lakes as Erie are often too much alivebut with undesirable forms of Algae etc. rendering them uninhabitable to desirable forms of plankton and fish. Commonly they stink. Much the same applies to the streams and rivers that take the run-off from agricultural and other lands and add the resulting waters to lakes and, ultimately, the sea. The complex ecosystems are destroyed as to natural balance, being replaced by simplified nightmares of sometimes 
poisonous blue-green algal scums and leaches or even worse. There can be no question that such changes amount to considerable local ecodisasters that are extending in their incidence and effects and will continue to do so unless drastic and often costly action is taken to counter them.

\section{SALT WATERS *}

Although the oft-cited contention of Cousteau (1971), that the intensity of life in the world's oceans and seas diminished by more than 30 per cent in the twenty-years span beginning in 1950 , is not widely supported by scientific investigations, there can be no question that there has already been considerable degradation of marine habitats and the cognate reduction of desirable life especially in such enclosed seas as the Mediterranean and Baltic. Pollution of various kinds is particularly to blame-by oils, sewage, and heavy-metal and other poisons and wastes (Hela, 1972). In addition, construction is apt to be heedlessly disruptive, eutrophication particularly by phosphates and nitrates is spreading, and heatpollution from nuclear and other industrial plants can be far from negligible (ibid.). For, like so many other adages, the one that 'everything ends up in the oceans' is by no means without its foundations of truth (Cousteau, 1971; Heyerdahl, 1972; Horsfield \& Stone, 1972). Furthermore, there have been drastic and increasing instances of over-fishing in recent years-and not merely of Antarctic whales and Atlantic Salmon! Thus my own son, diving recently on 27 coral reefs in the western Indian Ocean ranging from Seychelles to Madagascar, found only two that seemed to have their ecosystems sufficiently undisturbed for large predator fishes to be numerous and unafraid of divers (N. V. C. Polunin \& Frazier, 1974). These and Man's other uses and abuses of the seas could be, and in some instances already are, quite devastating-inter alia in disturbing ecological homeostasis (Ray, 1970). Clearly this many-pronged attack on the integrity of the oceans could herald an ecodisaster of the first magnitude. It has already struck forcibly in various ways in many inshore areas, so that it no longer seems reasonable to look on the oceans as an inexhaustible reservoir of food and more for Man; rather does their virtual 'death' seem a foreseeable possibility or at least conceivability (Ehrlich, 1969). Here we think of the present state of the enclosed seas of the world and of too many other important bodies of salt or brackish water, and of the problems of disposal of radioactive wastes. Particularly vulnerable are estuar-

* Abridged version of this section which has already been published in full as 'Ocean Ecodisasters' in the proceedings of the conference at which it was presented on invitation, namely Pacem in Maribus IV, International Ocean Institute, Msida Malta: pp. 355-9, 1974. ies and other inshore waters (W. E. Odum, 1970, 1974), on which it is thought that something like half of all commercially important species of marine animals are dependent at some stage or stages of their life-history. They are being polluted and otherwise despoiled by Man at a highly alarming rate.

That the Atlantic Ocean is apt to be badly surfacepolluted practically all the way across from about 160 kilometres off the north-west Coast of Africa to the eastern Caribbean region is now well-documented (Heyerdahl, 1971, 1972; A. R. G. Price, 1974), while recent correspondence indicates that the Pacific is following suit. The Atlantic pollution is mainly by oil-clots and brownish to pitch-black lumps or flakes of asphalt-like material up to about fifteen centimetres in diameter. But 'the surface water, containing large quantities of these lumps, was also covered intermittently by a shallow white foam such as develops from soap or synthetic washing-powder, while occasionally the Ocean's surface was even shining in all manner of colours as from gasoline. A vast quantity of dead coelenterates were floating among these oil lumps' (Heyerdahl, 1971). These observations were recorded near the Canary Islands, but were largely repeated in various longitudes practically across the Ocean. Among possible effects we will emphasize merely those on marine invertebrate life and Heyerdahl's remark (1972) concerning the oil lumps that they "were often densely covered with barnacles, crustaceans, and other marine hitch-hikers, and thus area tempting prey for fish. Whether swallowed or stuck in the delicate sieving mechanism of filterfeeding fish and whales, these constantly increasing oil-clots can hardly avoid affecting marine life.' More serious still is the fact that the various forms of pollution observed, including, 'opaque, greyish-green' ocean water that 'resembled harbour water at the outlet of city sewers', 'must inevitably reduce lightpenetration and hence photosynthesis by phytoplankton on which virtually all other life in the oceans depends' (Heyerdahl, 1971). That could lead to an ecodisaster of major proportions. And another which seems conceivable is that oil pollution, spread however thinly over vast ocean surfaces, might substantially reduce evaporation and ultimately atmospheric precipitation where it is needed as an essential prerequisite of most life on land.

My other chosen topic among various possibilities under this heading is the problem posed by persistent pesticides which find their way into the oceans and accumulate there. Even a very few parts of pesticide per thousand million of sea water can affect planktonic populations quite drastically. Most alarmingly undesirable in this connection are the petroleumderived halogenated hydrocarbons-particularly DDT and its derivatives-which are known to depress the 
photosynthetic or reproductive * activity of marine phytoplanktonic Algae, even in infinitesimally small amounts such as may already occur in places in the oceans (Wurster, 1968, 1969, 1972; Menzel et al., 1970). Although recent transects across the North Atlantic have suggested a decline in plankton productivity, this could well be due to other causes (e.g. Bryson, 1972b), and it is not considered likely, even if it seems possible, that any one of these causes would have a really substantial and widespread effect on marine productivity of food on one hand and oxygen on the other. But acting synergistically they might well have an extreme effect by creating an imbalance in the flora and fauna, upsetting the ecosystems, and so contributing to a duality of ecodisasters of the worst order.

\section{POLLUTANTS AND POISONS}

There is no clear answer to the natural question of 'When does a pollutant become a poison'-even if we define both terms in relation to a particular organism, such as Man-for it is a matter of relative effect, and this will depend also on other factors such as those of habitat and the state of health. Consequently it would seem best to treat pollutants and poisons together, though they range from chemically inert to extremely active substances. A pollutant may be defined as a substance or form of energy which causes pollution, the latter being the addition of any substance or form of energy to the environment in larger quantities than the local habitat can well accommodate. We have already mentioned some cases above. Particularly disruptive tend to be new chemicals etc. to which Nature is unaccustomed, and which consequently often turn out to be among the worst poisons -whether it be through killing organisms or otherwise disrupting the normal working of ecosystems. Thus with an alleged 1,000 new pollutants being added to the environment annually, and with the general volume of pollutants and level of pollution tending to increase with demographic growth, the situation of build-up of potentially obnoxious wastes alone seems to be deteriorating inexorably towards widespread ecodisastrous proportions. And when we note that the impact of many of the chemically active substances involved, whether alone or, particularly, together, is rarely sufficiently studied and often quite unknown, the mind boggles at the totality of conceivabilities. For different physical bodies and chemical substances can behave quite differently in different combinations and other circumstances, and where life with its vast variety and ever-changing facets and potentialities is involved, the possibilities mount up enormously.

\footnotetext{
* According to Dr. C. F. Wurster (in litt., September 1974) the effect 'is caused by a slowdown in the rate of reproduction leading to fewer cells, so that photosynthesis as measured by $\mathrm{C}^{14}$ uptake is reduced. In some cases the photosynthetic process itself appears to be inhibited. but in other cases this
} ber of cells is reduced.'
Moreover it seems clear that the sum total of what we actually know in and around the biological sciences is far surpassed-probably by many factors-by what we don't know. They may will be no more than in their infancy, despite the 'exponential' advance of recent decades!

We noted above how population balances could be widely upset by persistent pesticides in marine ecosystems, and this is known to have happened already in many freshwater and terrestrial ecosystems (Wurster, 1969, 1972; Woodwell, 1970). Nor does the simplification commonly engendered by Man-for example, in fostering monocultural agroecosystems-tend to relieve but rather to exacerbate this impress, especially when it leads to the explosive multiplication of resistent (and not always desirable) biota. For the circumscribed conditions imposed by many pollutants tend to favour small, rapidly reproducing organisms that are low in their food-chain-at the expense of larger but more slowly reproducing carnivores that are higher in their food-chain in which fat-soluble poisons build up (ibid.). With the intricate interdependence of biota sharing the same general habitat (N. Polunin, 1971), such effects can be widely if insidiously devastating, as are many of the other activities of Man (Murdoch, 1971; Ehrlich \& Ehrlich, 1972). We will mention here only the poisoning pollutions of some of the heavy metals, such as mercury and lead, the local effects of which are only too well known, but which could conceivably cause widespread ecodisasters if due watchfulness and caution are not practised (cf. Hutchinson \& Whitby, 1974). Often the unexpected items that creep up on us insidiously and then reach a point of no return are the most dangerous.

This prompts us to think of what has been called 'the dirtiest garbage of all'-the radioactive wastes of nuclear-fission power reactors and fuel-processing plants. Having listened to arguments 'back and forth' concerning the disposal of such wastes, which are likely to increase enormously as the seemingly inevitable 'energy crisis' mounts up in the industrial world, this layman in such matters is far from convinced that the entire situation does not loom as the basis of a major conceivable ecodisaster for the future (cf. Edsall, 1974). And this is barring all accidents and possibilities of nuclear holocaust, the lethal effects of which would be only too clear and the 'snowball' and other genetic effects more gradually emerging! Thus it seems safe to conclude with others that "Any man-made addition to the natural level [of ionizing radiation] increases the potential for biological harm'; for radioactivity builds up in the food-chains. Even fusion power may not be the answer, in view of the problems posed by the continued production of [radioactive] tritium (Cook, 1971). And then there are all manner of possibilities of human and technical failing, enemy action, 
and subversive sabotage. As for all-out nuclear war, whereas it 'probably would stop somewhere short of annihilation of the human species, environmental conditions for the survivors would be so changed that' anything now written on this topic would be of historical interest only (ibid.).

\section{METABOLIC DISRUPTION}

We have already referred more than once to the fundamental importance of photosynthesis as the main basis of almost all life on Earth, providing the food and energy not only of the producing green plants but also of the consuming animals together with their predators and whole hosts of parasites and saprophytesparticularly among the Fungi and Bacteria. Any disruption of photosynthesis will therefore attack the world's chief food-webs and component food-chains at their bases, and consequently disrupt ecosystems and change the delicate balance of Nature. This, as we have already seen, could conceivably happen in the oceans, inter alia through the depressive effects of even infinitesimally small amounts of organochlorine insecticides. It could also conceivably be brought about by other chemically active pollutants such as PCBs (M. Treshow in litt., 1973) or through reduction of light-penetration by particulate pollution. In each case there could either be reduction of total photosynthesis or selection of resistant organisms with consequent changes in the biotic components of the ecosystem. If we think of the vast array of existing and possible future pollutants that could have such effects, including a whole group of much-used herbicides which so interfere with photosynthesis that they cause target (and other) plants 'to die from lack of energy' (Ehrlich \& Ehrlich, 1972), we must feel concerned about the conceivable ecodisasters which they could effect, and should watch and guard against them accordingly. Nor, unfortunately, are such problems confined to the oceans-they are apt to apply even more drastically to bodies of fresh water which tend to be far more limited in extent and to be particularly vulnerable when they have low mineral contents and long renewal-times (Fryer, 1972). Effects on land are little known except in very limited areas, but could conceivably be widely extreme (M. Howard \& $M$. Treshow, MS.), as those of sulphurous fumes and some heavy metals certainly can be locally (cf. Hutchinson \& Whitby, 1974). Already it is known that ozone, originating particularly from photochemical oxidation of automobile effluents, can injure plants and, at least through chlorosis and reduction of effective foliage, depress their photosynthetic productivity, moreover having a selective effect which may be expected to change plant communities (Treshow, 1970; Treshow \& Stewart, 1973). Much the same is probably true of other forms of pollution, some of which can clog stomata or injure chloroplasts and in either case lead to reduction of photosynthesis and reproduction (Treshow, 1968, 1970). It is even said that special airpollution-resistant strains of some normally susceptible plants are developing, but of this I have so far been unable to obtain documentation. As D. L. Meadows (1973) indicates, there can be all manner of hidden dangers in any 'long delay between the generation of persistent pollutants and their appearance in the environment. Wherever the delay is long, vast amounts of pollution may be generated [and build up] before there is any possibility of effective countermeasures by society. Thus those counter-measures may come too late to avoid unacceptable pollution damage... the storage of radioactive wastes [is] a classic example of this problem'-see also $\mathrm{D}$. $\mathrm{H}$. Meadows et al. (1972).

Whether or not any of the above metabolicallyorientated conceivabilities (or more) ever result in major ecodisasters, we seem condemned to have to wait and see; the crux may well be Man's timely intervention, for which I am confident the capability in many directions still exists. Yet with such changes in the biosphere as we are now witnessing, and others which seem all too possible, one is prone to conjure up nightmares of a world of pampered monocultures, noxious weeds, squalid birds, cockroaches, sticklebacks, and scum-Algae, dominated by towering concrete and near-solid masses of humanity. Such a world might be just viable per se, but who would want to live in it! Personally I would rather not have been born, which is why already years ago I gave up most of my other activities to concentrate on fostering and propounding what I ardently hope is some ecological sense. This brings one to think of possibilities of derangement of the other most fundamental metabolic activity, namely respiration, on the vital significance of which we have already touched. It is said that respiration is widely affected by minute quantities of chlorinated hydrocarbons in aquatic ecosystems, most notably among marine phytoplankton, and if this tendency is operative also on land, where indeed are Man's modern chemical syntheses taking us while Nature ponders and tries out what to do with these unaccustomed interventions? Again the mind boggles to the extent of stifling the imagination. Nor does introduction of exotic plants and animals necessarily help, but so often precipitate fresh problems that it should be indulged in only after due study of all foreseeable effects (cf. Melville, 1970; Weber, 1971; Schofield, 1973).

Finally under this heading we come to a littleinvestigated 'rubbish heap' of other possible metabolic and allied physiological disruptions. That of transpiration, adding water vapour to the atmosphere, has 
already been treated under the general heading of the dangers of escalating devegetation, which, with its feedback loop of a drying atmosphere locally retarding revegetation, could, it seems to us, in time assume ecodisastrous proportions. In addition, ozone and other atmospheric pollution can clearly depress plant growth and reproduction, and not merely in cities (e.g. Treshow, 1970; H. Price \& Treshow, 1972; Hutchinson \& Whitby, 1974), though this seems unlikely to be sufficient to influence atmospheric moisture appreciably (M. Treshow in litt., 1973). Yet the possible effects of these and other injurious tendencies on the balanced working of the biosphere are so unpredictable that conjecture concerning them would at best be of little value and at worst alarming or even dangerous, though surely they should be closely watched as Man's population builds up and the incidence of general demophora goes on increasing (Vallentyne, 1972). Nor does it take drastic shocks to place ecosystems in jeopardy, but often more insidious changes which are all too apt to pass unnoticed.

\section{REPRODUCTION AND HEREDITY}

We have seen that Man's activities are widely and multifariously affecting environmental conditionslocally often drastically-with resultant disturbance of ecosystems and especially of their component biota. One of the ways in which this happens is through effects on reproduction, of which there are very numerous examples of often quite different kinds. Thus pollutants are widely effective in interfering with reproduction probably throughout the animal kingdom, a notable example of relatively recent inculcation by Man being the persistent pesticides such as DDT and other chlorinated hydrocarbons. These bring about reproductive failure in birds through causing them 'to lay abnormally thin-shelled eggs, which break prematurely in the nest and therefore do not produce chicks', while 'additional symptoms include late ovulation and nesting, abnormal behaviour, hatching failure, and failure to lay eggs' (Wurster, 1972). This is particularly the case with raptors and other birds high up in food-chains, due to increasing 'biological concentration' among cornivores (ibid.). These insidious substances are also known to be highly toxic to fish, being especially lethal to young fry after they hatch from contaminated eggs, with the result that whole fisheries are probably threatened and conceivable ecodisasters could thereby be engendered-especially as 'the concentrations of DDT at which fry mortality has been shown to occur under both controlled and field conditions are now being approached or equalled in some freshwater and marine fisheries' (ibid.). The effects of these substances on reproduction of such invertebrate animals as may survive after their application-com- monly to kill mosquitoes and other insect pests-are less well known but seem likely to be no less widespread and extreme at least in some instances. In addition there are numerous chemical and other pollutants, including radionuclides, which could have comparable effects, and the fact that these effects may not include spectacular 'kills' does not necessarily make their perpetrators the less dangerous but often more so in the long run.

As for plants, we have mentioned the selective effects of chlorinated hydrocarbons on phytoplankton which, inasmuch as it affects the build-up of food, will inevitably affect also the reproduction of the more sensitive organisms: for cells which are starved cannot go on dividing. As pointed out by Wurster (1972), selective poisoning and impaired reproduction of some algal species but not others could lead to an undesirable imbalance within the flora, resulting in a 'bloom' of the resistent species which could have profound ecological consequences. Much the same could occur on land, for example through the effect of such an atmospheric poison-in sufficient concentration in the wrong place - as ozone, in the manner postulated by H. Price \& Treshow (1972) and by Treshow \& Stewart (1973). Howard \& Treshow (MS.) have further demonstrated the acute sensitivity of understorey species in an aspen community to low concentrations of ozone, and how 'this sensitivity varied sufficiently that major shifts in community composition would be probable following only a year or two of exposure.' Where either the dominance or the soil microcosm is at all drastically changed, such effects could be very far-reaching; and although they may not as yet appear to assume ecodisastrous proportions, who is to know what the future may hold in store in these as in so many other connections where Man is constantly introducing new environmental factors to which plants and animals are not adjusted. Where would we be, for instance, if some devilishly insidious poison, already widespread in the biosphere, should suddenly be found to be attacking the chloroplasts or some reproductive phase of our cereal crops, which, belonging as they all do all to the same plant family, and having comparable anatomical and physiological characteristics, could be similarly susceptible!

Changes in environment also commonly have genetic effects, involving heritable characteristics and gene-pool potentialities. Thus pollution or other drastic disturbance may kill strains or even whole species of biota locally and hence preclude feedback mechanisms from development, through selection, of resistent species or genotypes within species (e.g. Frankel, 1970; Treshow \& Stewart, 1973). In addition, ionizing radiation and chemical mutagens, which can cause congenital defects (as well as desirable characteristics when used in plant and animal breeding), 
are a source of concern when such defects emerge in new generations. As pointed out by Ehrlich \& Ehrlich (1972) concerning 'the future quality of the human population. Every reasonable effort should be made to determine the extent of mutational hazards and to reduce them'- which also goes for other biota, starting with our main crops. Where would we be if a 'snowball' genetic effect should become widespread in ourselves or our main crops, producing disastrous results or even lethality! But here once again we enter a complex and highly involved field which must be left to appropriate specialists, who could probably already, and surely in the future will, write large tomes on it.

\section{HUMAN HEALTH}

Intense ionizing radiation and many environmental poisons can of course be lethal to Man. Less drastically, radiation can be carcinogenic as well as mutagenic, and the same is probably true of certain organic compounds which, for example, may exist as atmospheric pollutants. Particularly dangerous could be non-toxic ones which could go unnoticed until serious genetic damage had been done or cancers or other somatic problems engendered-for example through nitrogen dioxide (a common indirect product of car exhausts) combining with water to form nitrous acid, which may yield nitroso and other nitrogenous compounds, some of which can cause cancer at least in mice as can cigarette smoke apparently in humans (Murdoch, 1971). Such 'microenvironmental' effects seem to be bound up with more general ones, and in the words of Ehrlich \& Ehrlich (1972) 'If current trends are allowed to continue, death from air pollution will become obtrusive'. It has even been claimed that cancer may be preponderantly a function of pollution, and that if current trends continue the majority of humans will in time become affected by it (Goldsmith, 1973). In any case, with the World Health Organization insisting that "More and more [chemical] compounds are found to be definitely carcinogenic', we had better watch out!

Nor does the possibility of some devastating virus or bacterial mutant or cardiovascular pandemic seem to be rendered less but rather more conceivable in these days of rapid though stressful transport throughout the world-in spite of the protestations of many of our medical friends that they have things under control, so that such a calamity would be unthinkable to them. But how about a world already decimated and widely weakened by thermonuclear holocaust and/or global famine; all these things are, unfortunately, conceivable, and should be squarely faced as such. For, sooner or later, something will have to give way to an expanding and ever-moreprofligate human population on a finite globe. Might not some lethal influenza or other mutant virus be engendered by nuclear warfare and disrupted Man be unable to produce the antidote in time? At present the ease of transport particularly between badly crowded communities, with deplorable physical weakening due to pampering and instability due to mental stress, would seem unpromising bases from which to combat a pandemic of a sudden very serious infection. Nor does our belief in the sanctity of human life-even, in some creeds, from conception - help us, with its concomitant of keeping alive the hopelessly infirm in mounting numbers even when they want to depart from their misery. And meanwhile there seems to be an ever-increasing undercurrent of anarchical disruptions by kidnapping, skyjacking, violent strikes, train-wrecking, bombing, assassination, and other forms of extreme thuggery, while mental and venerial diseases burgeon. In this tense modern world it seems increasingly difficult to think of Utopia, as population pressures and strife build up and there is less of the world's limited 'cake' for each of us.

This brings us to think of food, and the increasing difficulties, to which we have already referred, of feeding the world's ever-increasing population. This 'most pressing factor limiting the capacity of the Earth to support Homo sapiens' (Ehrlich \& Ehrlich, 1972) has already been well treated by those and various other recent authors, so we need not dwell on it here. The prospects of adequately feeding the world's population are, however, not improving but widely getting more gloomy (ibid. and D. H. Meadows et al., 1972), in the manner of many other human prospects as we have already seen. And with food shortages and imbalances come dietary deficiencies and all manner of other health problems. Probably already about one-half, and surely more than onequarter, of the world's human population are to some extent 'hungry' (ibid.), so that the conclusion seems inescapable that widespread famine is all-too-likely some time in the future; with its foreseeable disruption of ecosystems and desecration of national parks and reserves, not to mention the seemingly inevitable rape of all that can be seized to allay the pangs and worse of hunger, this has to be considered among our all-too-conceivable ecodisasters. For it is a familiar facet of human and indeed all higher-animal nature that our actions and reactions tend to become more and more extreme the harder we are pressed, so that mankind as a whole cannot, for example, answer for the doings of a nation at war. Indeed I have heard the belief solemnly expressed by a highly-respected senior zoologist of wide ecological experience, presumably with cases of population swarming in mind, that there will be no need to invoke world faminethat people will come to killing one another in sufficient numbers to take care of the population problem. 


\section{SOCIAL BREAKDOWN}

Whether or not the world has embarked on a vicious spiral of selfish grab and strife, there can be no question that mankind is facing grave shortages of scarce raw materials and that over-development in some regions is exacerbating the deteriorating general situation. By over-development in this context I mean man-made changes that are out-of-step with environmental realities and hence place an undue strain on biospheric capabilities. As a result, an era of national and regional grabs of scarce necessities or industrial bases is all too foreseeable. Think, if you desire, of Icelandic cod as renewable, but of NearEast oil as once-for-all. Both could cause wars as indeed such situations have done in the past; but now Man has the means of escalating his disputes to nuclear holocaust, and it even seems conceivable that such an event could be started by a fanatic or a sufficiently harassed leader pushing a button (already people are committing suicide all over the world in any case). Where would the environment be then, and what would become of the biosphere with all its delicate adjustments of infinite complexity! I'll leave this to your imagination, scarcely daring to give vent to my own.

Current doubts about traditional fuel supplies and seemingly inevitable shortages of crisis dimensions have led to an upsurge of interest in alternative sources of energy and power (H. T. Odum, 1971; Bockris, in press; Hirsch \& Rice, in press), use of most of which would pose serious environmental problems. Especially is there grave concern about the environmental hazards of large-scale use of nuclear power as already indicated. Even large-scale damming, strip-mining, and other works of 'environmental face-lifting', can have serious repercussions that could assume ecodisastrous proportions (Kassas, 1972; Goldman, 1972a, $1972 b$ ). Also disturbing in this connection are such human reactions as rioting and senseless destruction of public transport vehicles e.g. in Japan, and in many countries the chronic strikes and violent demonstrations proving an easy prey to anarchy and undesirable 'leadership'. Especially where supplies and services are threatened or 'tribalism' of any kind is rife, people living in crowded conditions are apt to go collectively berserk-for example under the stress of a long, hot summer-and to ignore all considerations of environment in the surge for some primitive self-gratification. Here again the ecodisastrous conceivabilities are all too clear in the ecological perspective. The effects of unenlightened industrialization, especially by huge multinational corporations sometimes having financial powers far exceeding those of entire sovereign states, and often exercising poor control from a distant headquarters, can be widely disastrous - to the extent that it is ardently to be hoped that scientifically based environmental impact studies will soon be required to be made and approved on an international basis before major new or expanded development is indulged in. Organizing and implementing such a vital service to mankind as a whole would seem to present a fine challenge for the relatively new United Nations Environment Programme to take up.

Highly disturbing to those of us who are concerned about the longer-term future is the threat to law and order posed by multiplying delinquency, increasing crime, drug-taking, and psychological illness linked with tensions due to competition and personal stress (cf. the preceding section). And although this is largely bound up with extreme urbanization, which engenders its own set of problems and indeed was one of our main headings that had to be deleted for lack of space, it does not appear to be either a necessary corollary of this or by any means limited thereto. Vandalism and other wanton damage are apt to occur in rural as well as urban environments, and the impress of tourism can ruin attractive and productive areasespecially in the absence of proper planning (Benthem, 1973). For where that impress is ever more extreme, with ever-increasing numbers of human beings making ever-heavier demands on a limited area-not to mention its flora and fauna-the tendency is commonly towards ecological disruption and consequent ecosystem breakdown. This is not social breakdown; but it can have similarly disastrous effects locally, and tends to be ever-expanding. The basic cause lies in Man's failure to control his own numbers, with their natural needs and understandable ambitions, though he now knows how. Yet it is the one vital thing he does not do!

\section{CONCLUSION AND SUMMARY}

Even if, as many of us believe, 'there is time to avoid the abyss' of non-survival, there is no time for complacency. Rather is there need for eternal vigilance, scientific monitoring, international legal and other enlightened controls, and often very costly action. For Man is inexorably changing the world, though often insidiously and quite unintentionally. Already he has the knowledge and wherewithal to control his numbers, effects, and very destiny, maintaining the biosphere for himself and to some extent for Nature; but has he the collective wisdom? And what are the limits of his folly? It might be thought that many of our chosen items touched on above are either local or not concerned with the environment as a whole, and hence would not constitute real ecodisasters; but when we look just a little 'below the surface', we realize that they could engender in the long run quite disastrous effects on the habitat and life- 
support system of Man which, with his present alltoo-heavy impress, could mean the far wider environment of Nature and even the entire biosphere. Meanwhile Man's objective in this age of ecological enlightenment should surely be to maintain optimum diversity in the biosphere-with due emphasis on the 'optimum' having regard to the direct needs of Nature as well as of himself.

With Man now the unquestioned superdominant of the world, yet continuing to increase his numbers to the extent of projected doubling in $30-40$ years and doubling again thereafter, there are thrust upon us an ever-increasing number and burden of conceivable ecodisasters, many of which we have touched on above. Others can already be foreseen and yet others will doubtless emerge. None seems inevitable in itself, at least in widespread magnitude, and few appear to be at all likely; but still something has got to happen to check the projected mounting demomass, and it seems reasonable to expect it to be one or more of cur listed conceivabilities. Which this may turn out to be, presumably sparking othets and altogether changing the world even more precipitously than has been the case of late, we can only conjecture. Of the major threats or remedies-world famine, nuclear holocaust, pandemic pestilence, anarchical strife, or natural or peacefull medical etc. control of population-it seems at present that the first is the most likely, with Nature taking her course. To those of us who are not doomwatchers, but believe in the resilience and cunning of manking to survive, it is nevertheless evident that something is bound to happen; for we cannot continue indefinitely to expand exponentially on a finite globe. And as to what this something turns out to be, we should remember that outside chances do have a way of happening, and to be the more devastating in effect because of their unexpectedness leaving us unprepared. So we should watch meticulously for our conceivable ecodisasters, be forewarned to take action in time, and look out for others that are still not conceived; for even if, with chances small, the possibility of minor events happening can often be ignored, with major devastating ones we cannot afford to leave ourselves to the mercy of even very small chances. Surely some of these are such that all good globalists, geopoliticians, and even statisticians, must agree.

\section{References \\ (Commonly suggesting further reading)}

Attiwill, Peter M. (1971). Atmospheric carbon dioxide and the biosphere. Environmental Pollution, 1 (4), pp. 249-61, 1 fig.

BENTHEM, Roelof J. (1973). Recreational and environmental planning. Biological Conservation, 5 (1), pp. 1-5.

BockRIs, John O'M. (in press). The coming energy crisis and solar sources. Environmental Conservation.

Bryson, Reid A. (1972a). Climatic modification by air pollution. Pp. 133-55 and 12 figs in The Environmental Future (Ed. Nicholas Polunin, q.v.).
Bryson, Reid A. (1972b). [Intervention.] Ibid.pp. 162-3.

Cloudsley-Thompson, J. L. (1974). The expanding Sahara. Environmental Conservation, 1 (1), pp. 5-14, 7 figs.

Cook, Earl (1971). Ionizing radiation. Pp. 254-78 in Murdoch (q.v.).

Cousteau, Jacques-Yves (1971). Statement on global marine degradation. Biological Conservation, 4 (1), pp. 61-5.

CURRY-LindahL, Kai (1974a). Conservation problems and progress in equatorial African countries. Environmental Conservation, 1 (2), pp. 111-22, map.

CURry-Lindahl, Kai $(1974 b)$. Conservation problems and progress in northern and southern African countries. Environmental Conservation, 1 (4), [in proof].

EDSALL, John T. (1974). Hazards of nuclear fission power and the choice of alternatives. Environmental Conservation, 1 (1), pp. 21-30.

EhrLich, Paul R. (1969). Eco-catastrophe. Ramparts, 8, September, pp. 24-8.

EHRLICH, Paul R. (1974). Human population and environmental problems. Environmental Conservation, 1 (1), pp. 15-20.

Ehrlich, Paul R. \& EhrLich, Anne H. (1972). Population, Resources, Environment: Issues in Human Ecology (2nd edn). W. H. Freeman, San Francisco: xiv +509 pp., illustr.

Ehrlich, Paul R., Ehrlich, Anne H. \& Holdren, John P. (1973). Human Ecology: Problems and Solutions. W. H. Freeman, San Francisco: xi + 304 pp., illustr.

FAO (1972). Annual Fertilizer Review. Food and Agriculture Organization of the United Nations, Rome: xviii +191 pp.

Frankel, Sir Otto H. (1970). Genetic conservation of plants useful to Man. Biological Conservation, 2 (3), pp. 162-9.

FrEMLIN, J. H. (1964). How many people can the world support? New Scientist, 24, pp. 285-7, illustr.

FrYER, Geoffrey (1972). Conservation of the Great Lakes of East Africa: a lesson and a warning. Biological Conservation, 4 (4), pp. 256-62, 4 figs.

Goldman, Marshall I. (1972a). [Intervention.] Pp. 240-2 in The Environmental Future (Ed. Nicholas Polunin, q.v.).

Goldman, Marshall I. (1972b). The Spoils of Progress: Environmental Pollution in the Soviet Union. MIT Press, Cambridge, Mass., \& London, England: $\mathrm{xi}+372$ pp., illustr.

GolDSMITH, Edward (1973). Ecologistes de tous les pays, battezvous! Gulliver: Forum des lettres, des arts et de la vie quotidienne, No. 6, pp. 32-9.

HeLA, Ilmo (1972). Marine productivity and pollution. Pp. 24972 in The Environmental Future (Ed. Nicholas Polunin, q.v.).

Henderson, Julia (1972). [Chairman's comment.] P. 568 in The Environmental Future (Ed. Nicholas Polunin, q.v.).

HEYERDAHL, Thor (1971). Atlantic Ocean pollution and biota observed by the 'Ra' Expeditions. Biological Conservation, 3 (3), pp. 164-7, map.

HeYerdahl, Thor (1972). Addendum. Pp. 286-9 in The Environmental Future (Ed. Nicholas Polunin, q.v.).

HiRsCH, Robert L. \& Rice, William L. R. (in press). Nuclear fusion power and the environment. Environmental Conservation.

Horsfield, Brenda \& Stone, Peter B. (1972). The Great Ocean Business. Hodder \& Stoughton, London: $\mathrm{x}+360 \mathrm{pp}$., illustr.

Howard, Max \& Treshow, Michael (MS.). Impact of Ozone on Reproductive Potential. Typescript, $17 \mathrm{pp}$.

Hutchinson, T. C. \& Whitby, L. M. (1974). Heavy-metal pollution in the Sudbury mining region of Canada, I. Soil and vegetation contamination by nickel, copper, and other metals. Environmental Conservation, 1(2), pp. 123-32, map.

JOHNSON, Francis S. (1970). The balance of atmospheric oxygen and carbon dioxide. Biological Conservation, 2(2), pp. 83-9.

JoHnson, Stanley (1970). Life Without Birth: A Journey Through the Third World in Search of the Population Explosion. Heinemann, London: xiii +364 pp., illustr. 
Johnston, Harold S. (1972). Catalytic reduction of stratospheric ozone. Pp. 175-7 in The Environmental Future (Ed. Nicholas Polunin, q.v.).

JoHnston, Harold S. (1974). Pollution of the stratosphere. Environmental Conservation, 1(3), pp. 163-176, illustr.

KASSAS, M. (1972). Ecological consequences of water development projects. Pp. 215-35 (and following Discussion) in The Environmental Future (Ed. Nicholas Polunin, q.v.).

KovDA, Viktor A. (1972). The world's soils and human activity. Pp. 359-81 in The Environmental Future (Ed. Nicholas Polunin, q.r.).

Meadows, Dennis L. (1973). Nuclear energy and growth. Science, 179, pp. 855-6.

Meadows, Donella H., Meadows, Dennis L., Randers, Jorgen \& BeHRENS, William W. III (1972). The Limits to Growth. A Report of the Club of Rome's Project on the Predicament of Mankind. A Potomic Associates Book, Universe Books, New York: 205 pp., illustr.

Melville, Ronald (1970). Plant conservation and the Red Book. Biological Conservation, 2(3), pp. 185-8.

Menzel, David W., Anderson, Judith \& RandtKe, Ann (1970). Marine phytoplankton vary in their response to chlorinated hydrocarbons. Science, 167, pp. 1724-6, fig.

Murdoch, William W. (Ed.) (1971). Environment: Resources, Pollution \& Society. Sinauer Associates, Stamford, Connecticut: vii +440 pp., illustr.

NACE, Raymond L. (1967). Water resources: A global problem with local roots. Environmental Science and Technology, 1(7), pp. 550-60, illustr.

National ACADEMy of Sciences/National ACAdemy of ENGINEERING [as NAS/NAE] (1973). Biological Impacts of Increased Intensities of Solar Ultraviolet Radiation. National Academy of Sciences/National Academy of Engineering Washington, D.C.: vii +46 pp., 4 figs.

Odum, Howard T. (1971). Environment, Power, and Society. Wiley-Interscience, New York etc: ix +331 pp., illustr.

ODum, William E. (1970). Insidious alteration of the estuarine environment. Transactions of the American Fisheries Society, 99(4), pp. 836-47.

Odum, William E. (1974). Potential effects of aquaculture on inshore coastal waters. Environmental Conservation, 1 (3) pp. 225-30.

Polunin, Nicholas (1971). Vegetation and the animal habitat. Le Naturaliste Canadien (Travaux dédiés à la mémoire du Professeur Jacques Rousseau, 1905-1970), 83(3), pp. 515-28.

PoLUNIN, Nicholas (Ed.) (1972). The Environmental Future. Macmillan, London \& Basingstoke, and Barnes \& Noble, New York: xiv +660 pp., illustr.

Polunin, Nicholas [as 'N.P.'] (1973). Editorial: Scientists relieved. Biological Conservation, 5(3), p. 159.

Polunin, Nicholas (1974). One World and Its Biosphere. Invitational paper delivered to 25th Annual Meeting of the British Student Health Association, held at Cambridge, England, 5-10 July 1973, and published in its Proceedings, pp. 23-31.
Polunin, N. V. C. \& Frazier, J. G. (1974). Diving reconnaissance of 27 western Indian Ocean coral reefs. Environmental Conservation, 1(1), pp. 71-2, 3 figs.

President's Science Advisory Committee (1967). The World Food Problem. Report of the Panel on the World's Food Supply, the White House, Washington, D.C.: Vol. I, xxv +127 pp., figs; Vol. II, xxi +772 pp., figs.; Vol. III, $\mathrm{xxi}+332$ pp., figs.

Price, A. R. G. (1974). A further look at pollution in the Atlantic Ocean. Biological Conservation, 5(4), pp. 297-8, map.

Price, Harvey \& Treshow, Michael (1972). Effects of Ozone on the Growth and Reproduction of Grasses. Proc. Internat. Air Pollut. Conf., Melbourne, Australia, pp. 275-80.

RAY, Carleton (1970). Ecology, law, and the 'marine revolution'. Biological Conservation, 3(1), pp. 7-17, fig. (Reprinted with permission at least twice elsewhere.)

Schofield, Eileen K. (1973). Galapagos flora: the threat of introduced plants. Biological Conservation, 5(1), pp. 48-51, 4 figs.

SCIENTIFIC AMERICAN (1971). Man and the Ecosphere. Readings from Scientific American with commentaries by Paul R. Ehrlich, John P Holden \& Richard W. Holm. W. H. Freeman, San Francisco: vii +307 pp., illustr.

Treshow, Michael (1968). The impact of air pollutants on plant populations. Phytopathology, 58, pp. 1103-13.

Treshow, Michael (1970). The Environment and Plant Response. McGraw-Hill, New York: Xv +422 pp., illustr.

Treshow, Michael \& Stewart, Dennis (1973). Ozone sensitivity of plants in natural communities. Biological Conservation, 5(3), pp. 209-14, illustr.

VALLENTYNE, John R. (1972). Freshwater supplies and pollution: Effects of the demophoric explosion on water and Man. Pp. 181-99 in The Environmental Future (Ed. Nicholas Polunin, q.v.)

WeBER, Daniel (1971). Pinta, Galápagos: une île à sauver. Biological Conservation, 2(2), pp. 125-8, 4 figs.

Wendland, Wayne M. \& Bryson, Reid A. (1970). Atmospheric dustiness, Man, and climatic change. Biological Conservation, 2(2), pp. 125-8, 4 figs.

Woodwell, G. M. (1970). Effects of pollution on the structure and physiology of ecosystems. Science, 168, pp. 429-33.

Worthington, E. Barton (1972). Sustained biological productivity. Pp. 397-411 in The Environmental Future (Ed. Nicholas Polunin, q.v.).

Wurster, Charles F., Jr (1968). DDT reduces photosynthesis by marine phytoplankton. Science, 159, pp. 1474-5, 2 figs.

Wurster, Charles F., Jr (1969). Chlorinated hydrocarbon insecticides and the world ecosystem. Biological Conservation, 1(2), pp. 123-9.

Wurster, Charles F., Jr (1972), Effects of insecticides. Pp. 293310 and fig. in The Environmental Future (Ed. Nicholas Polunin, q.v.).

\section{Impact of Pollutants on Plankton Communities}

Most investigations involving the toxicity of various pollutants to aquatic organisms are conducted in laboratory situations where the sensitivity of an individual organism or isolated population is evaluated. The applicability of these tests to the natural environment has been questioned, however, for organisms do not exist in isolation in Naturenor do they usually live under the ideal conditions of the laboratory. Because species generally interact with one another in Nature, there is a need to evaluate the responses of whole communities and ecosystems to pollutants, as well as the behaviour of isolated populations.
Pollutants often seem to fall into one of two categories They may be chemicals that are toxic to some or all organisms, as in the case of certain exotic pesticides, heavy metals, or crude oil; or they can be relatively non-toxic chemicals, such as those found, for example, in domestic sewage, that often lead to an undesirable degree of eutrophication. The latter group of pollutants have sometimes been found to affect species diversity (Palmer, 1963; Patrick, 1963; Borowitzka, 1972) and species composition (Ryther, 1954 ) in algal communities, though their effects may be less severe than those caused by toxic pollutants (Edwards, 1972). 